\title{
Ecosystem modeling analysis of size-structured phytoplankton dynamics in the York River estuary, Virginia (USA). II. Use of a plankton ecosystem model for investigating controlling factors on phytoplankton and nutrient dynamics
}

\author{
Yongsik Sin* ${ }^{*}$ Richard L. Wetzel ${ }^{* *}$ \\ School of Marine Science, Virginia Institute of Marine Science (VIMS), College of William and Mary, Gloucester Point, \\ Virginia 23062, USA
}

\begin{abstract}
An ecosystem simulation model was used to investigate potential mechanisms controlling the size-structured phytoplankton and nutrient dynamics in the mesohaline zone of the York River estuary. The York River ecosystem model (Sin \& Wetzel 2001, Mar Ecol Prog Ser 228:75-90)was calibrated and validated based on field observations and laboratory measurements prior to the exercises reported here. Analyses of model sensitivity to state variable changes and parameter variations were performed to examine hypotheses proposed from previous studies regarding controls on phytoplankton and nutrient dynamics in the York River estuary. The model results supported the general view that phytoplankton dynamics may be controlled by abiotic mechanisms (i.e. bottom-up control) rather than biotic, trophic interactions in the estuary. Larger mesozooplankton appear to be controlled by top-down mechanisms. Model sensitivity studies showed that small phytoplankton cells (pico-, nano-) are more likely to be regulated by temperature and light, whereas large cells (micro-) are more likely to be regulated by physical processes such as advection and tidal mixing. Microphytoplankton blooms during winter-spring resulted from a combination of vertical advection and diffusion of phytoplankton cells rather than in situ production.
\end{abstract}

KEY WORDS: York River estuary $\cdot$ Size-structured phytoplankton and nutrient dynamics $\cdot$ Ecosystem simulation model $\cdot$ Controlling mechanisms $\cdot$ Advection and diffusion

\section{INTRODUCTION}

Phytoplankton dynamics in aquatic environments may be regulated by abiotic mechanisms (nutrient fluxes related to physical-chemical variability, i.e. bottom-up control) and biotic processes (trophic

\footnotetext{
${ }^{*}$ Present address: Division of Ocean System Engineering, Mokpo National Maritime University, 571-2 Chukyo-dong, Mokpo, Chonnan 530-729, S. Korea

${ }^{* *}$ Corresponding author. E-mail: dick@vims.edu
}

interactions, i.e. top-down control: Carpenter et al. 1987, Kivi et al. 1993, Armstrong 1994, Caraco et al. 1997). There has been continuing controversy and debate over the relative importance of bottom-up versus top-down controls and established concepts of resource competition (Tilman 1982) and trophic cascade (Carpenter et al. 1985) for many years. In riverdominated estuaries, these controlling mechanisms interact with phytoplankton in complex ways, mainly due to freshwater and tidal energy inputs into the system (Alpine \& Cloern 1992, Pennock \& Sharp 1994, Cloern 1996). Temporal variations in river-dis- 
charge to an estuary can affect phytoplankton production, biomass accumulation and size structure or taxon composition through several processes: (1) altering inputs of nutrients from the surrounding watershed; (2) altering light availability by way of estuarine gravitational circulation, stratification, and changing the turbidity maximum zone along the estuary; (3) altering rates of dilution or advection of phytoplankton $_{i}$ (4) altering the amount of detrital or suspended organic matter supporting heterotrophs in an estuarine system (e.g. Malone \& Chervin 1979, Malone et al. 1980, 1988, Cloern et al. 1983, Pennock 1985, Gallegos et al. 1992, Madariaga et al. 1992, Boyer et al. 1993). While seasonal and interannual fluctuations in river discharge produce low-frequency oscillations in the phytoplankton populations, variations in tides (tidal mixing) result in high-frequency oscillations (Haas 1975, Ray et al. 1989, Aksnes \& Lie 1990, Cloern 1991).

In previous studies, phytoplankton and nutrient dynamics were investigated by analyzing US Environmental Protection Agency (EPA) long-term monitoring data (Sin et al. 1999) and summarizing the results of an annual sampling program in the York River estuary,

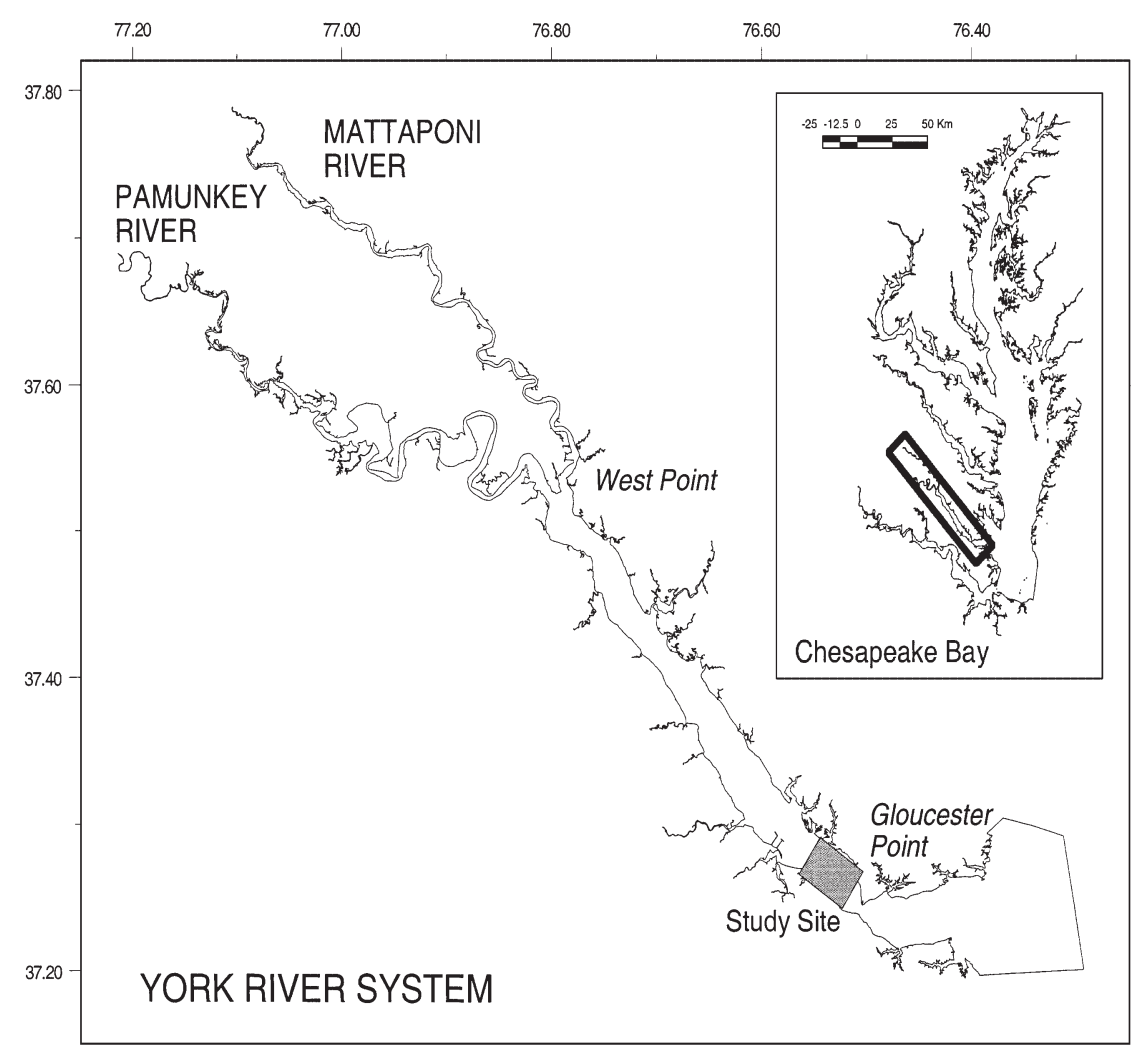

Fig. 1. Area of model application ( $\square$ ) in the mesohaline zone of the York River estuarine system. Water samples were collected at the site over an annual cycle (see Sin et al. 2000)
Virginia (Sin et al. 2000). These studies summarized the general spatial-temporal characteristics of phytoplankton biomass and size structure as well as nutrient dynamics in the York River estuary. Potential controlling factors were documented from the results, but it was difficult to identify the major controlling factors for the phytoplankton community due to the complexity of interactions between phytoplankton and other plankton, and between phytoplankton and the highly variable physical-chemical environment.

The principal goal of this modeling effort was to investigate major mechanisms controlling size-fractionated phytoplankton and nutrient dynamics in the mesohaline zone of the York River estuary, Virginia, by using the York River ecosystem process model (Sin \& Wetzel 2002).

\section{MATERIALS AND METHODS}

\section{Area of model application}

The area of model application is located in the mesohaline zone of the York River estuarine system, a sub-estuary of the Chesapeake Bay. The estuarine system is composed of 3 rivers: the York, Pamunkey, and Mattaponi (Fig. 1). The York River is formed by the confluence of the Pamunkey and Mattaponi rivers at West Point $(48 \mathrm{~km}$ from its mouth). Total average freshwater discharge to the river system is 70 $\mathrm{m}^{3} \mathrm{~s}^{-1}$ (Hyer 1977). Salinity distribution in the York River system is affected by the interaction of freshwater, salt water, tidal energy and wind. Salinity gradients between the surface and bottom layers are influenced by neap and spring tidal cycles, with destratification of the water column occuring at high spring tides and stratification developing during the intervening periods (Haas 1975). The area of model application is located in the mesohaline zone, $13 \mathrm{~km}$ from the mouth of the York River estuary (Fig. 1). Average water depth in this region is $16.7 \mathrm{~m}$, and salinity ranged from 12.0 to 17.5 in surface water and from 16.0 to 22.2 in bottom water during the period August 1996 to June 1997.

Model description. A tidally averaged plankton model with 12 state variables was developed using a combination of allometric relationships, den- 
sity-dependent feedback-control functions and explicit hydrodynamics. The model was calibrated and validated using values from the literature and field observations from the York River estuary. Sensitivity analyses on the model was performed and indicated that the model was relatively robust, since it was not highly sensitive to changes $( \pm 20 \%)$ in most parameters which were not specified in the literature or field observations. The ecosystem model was used to investigate potential mechanisms controlling size-structured phytoplankton and nutrient dynamics. The conceptual, mathematical structure and results of sensitivity analyses of the York River ecosystem model are given in Sin \& Wetzel 2002.

Model analyses. To identify potential mechanisms controlling phytoplankton and nutrient dynamics, the model studies focused on sensitivity analyses. The effect of variations in coefficients related to or values of parameters hypothesized to be the major controlling factors of phytoplankton dynamics in the York River system were investigated after model calibration and validation. Each parameter was varied relative to nominal values in individual model runs.

To examine the effect of changes in forcing variables, model sensitivity was tested for the forcing variables given $\pm 10 \mathrm{E} \mathrm{m}^{-2} \mathrm{~d}^{-1}$ change in incident solar radiation, $\pm 2^{\circ} \mathrm{C}$ temperature change, $\pm 20 \%$ changes in the light-attenuation coefficient and top-to-bottom salinity difference. Top-to-bottom salinity difference was included in the analyses since it is an indicator of water-column stratification and destratification. Effects of changes in boundary conditions were investigated given \pm 10 and $\pm 20 \%$ changes in incoming source water from upriver and bottom waters respectively. To assess the potential impact of the changes described above, a forcing variable or constant was considered as 'sensitive' (controlling factor for a state variable) if the specified change in the values of variables produced $\mathrm{a} \geq 10 \%$ change in $3 \mathrm{yr}$ average concentrations of the state variables relative to the nominal model run. Effects of physical processes including diffusion and advection on phytoplankton and nutrient dynamics were assessed by removing diffusion, longitudinal advection, vertical advection and diffusion + advection processes from the model in the sensitivity analyses. A physical process was considered to be 'sensitive' if removal of the process resulted in a $\geq 100 \%$ change in 3 yr average concentrations of the state variables relative to the nominal model run. In the model sensitivity analyses, the root mean-square deviation (RMS) between the daily values of state variables from nominal model runs and the outputs from sensitivity runs was computed (Sin \& Wetzel 2002) and compared with the means of each state variable for the nominal runs.

\section{RESULTS}

\section{Model sensitivity: parameter variation}

Table 1 presents the computed RMS values of sensitivity runs for a $\pm 20 \%$ change in selected parameters and the average \% change in state variables for pico-, nano- and microphytoplankton, ammonium, nitrite+ nitrate and orthophosphate. Picophytoplankton (PP) were marginally sensitive to changes in certain parameter values, demonstrating changes of less than $6 \%$ in average concentrations relative to the nominal model run. Nanophytoplankton (NP) were generally insensitive to changes in parameters related to metabolic processes, although they appeared sensitive (9\%) to a change in cell size (mass, $M$ ). In contrast to small cells, large cells (microphytoplankton, MP) were sensitive to changes in $M$ and bed-shear velocity $\left(u_{*}\right)$, exhibiting a $14 \%$ and a $12 \%$ change in average concentration respectively. The effects of changes in cell size appeared to increase with increasing cell size. The results suggest

Table 1 . Results of sensitivity analyses $( \pm 20 \%$ change in parameter values) for phytoplankton and nutrient components in the York River ecosystem model. -: \% change $<5 \%$ omitted; ${ }^{*}$ : \% change $>10 \%$, 'sensitive'

\begin{tabular}{|c|c|c|}
\hline $\begin{array}{c}\text { State variable } \\
\text { Parameter }\end{array}$ & Average RMS & $\%$ change \\
\hline \multicolumn{3}{|l|}{ Picophytoplankton (PP) } \\
\hline Optimum light $\left(I_{0}\right)$ & 0.17 & - \\
\hline Cell mass $(M)$ & 0.15 & - \\
\hline Mortality rate $\left(r_{\mathrm{m}}\right)$ & 0.21 & 5.3 \\
\hline Exudation rate $\left(r_{\mathrm{ex}}\right)$ & 0.21 & 5.3 \\
\hline Grazer preference $\left(P_{i j}\right)$ & 0.12 & - \\
\hline Bed-shear velocity $(u)$. & 0.13 & - \\
\hline \multicolumn{3}{|l|}{ Nanophytoplankton (NP) } \\
\hline Optimum light $\left(I_{0}\right)$ & 0.14 & - \\
\hline Cell mass $(M)$ & 1.06 & 9.0 \\
\hline Mortality rate $\left(r_{\mathrm{m}}\right)$ & 0.05 & - \\
\hline Exudation rate $\left(r_{\mathrm{ex}}\right)$ & 0.07 & - \\
\hline Grazer preference $\left(P_{i j}\right)$ & 0.29 & - \\
\hline Bed-shear velocity $(u)$. & 0.25 & - \\
\hline \multicolumn{3}{|l|}{ Microphytoplankton (MP) } \\
\hline Optimum light $\left(I_{0}\right)$ & 0.09 & _- \\
\hline Cell mass $(M)$ & 1.02 & $14.5^{\circ}$ \\
\hline Mortality rate $\left(r_{\mathrm{m}}\right)$ & 0.43 & 6.1 \\
\hline Exudation rate $\left(r_{\mathrm{ex}}\right)$ & 0.43 & 6.1 \\
\hline Grazer preference $\left(P_{i j}\right)$ & 0.15 & - \\
\hline Bed-shear velocity $(u)$. & 0.86 & $12.3^{\circ}$ \\
\hline \multicolumn{3}{|l|}{$\mathrm{NH}_{4}^{+}(\mathrm{N} 1)$} \\
\hline C:N ratio $(\mathrm{C}: \mathrm{N})$ & 0.003 & $12.8^{\circ}$ \\
\hline Bed-shear velocity $(u)$. & 0.042 & - \\
\hline \multicolumn{3}{|l|}{$\mathrm{NO}_{2}^{-}+\mathrm{NO}_{3}^{-}(\mathrm{N} 2)$} \\
\hline Denitrification & 0.007 & 8.7 \\
\hline Bed-shear velocity $(u)$. & 0.092 & - \\
\hline \multicolumn{3}{|l|}{$\mathrm{PO}_{4}^{3-}(\mathrm{P})$} \\
\hline $\mathrm{C}: \mathrm{P}$ ratio $(\mathrm{C}: \mathrm{P})$ & 0.0008 & $10.5^{\circ}$ \\
\hline Bed-shear velocity $(u)$. & 0.006 & - \\
\hline
\end{tabular}


Table 2. Results (average RMS and \% change) of sensitivity analyses for state variables given specified changes in values of forcing variables and boundary conditions. -: \% change <10\%. PP: picophytoplankton; NP: nanophytoplankton; MP: microphytoplankton; HB: heterotrophic bacteria; HFC: heterotrophic flagellate + ciliates; Z1: microzooplankton, Z2: mesozooplankton; N1: ammonium; N2: nitrite + nitrate; P: orthophosphate

\begin{tabular}{|c|c|c|c|c|c|c|c|c|c|c|c|c|}
\hline \multirow{2}{*}{ Description } & \multirow[b]{2}{*}{ PP } & \multirow[b]{2}{*}{ NP } & \multirow[b]{2}{*}{ MP } & \multirow[b]{2}{*}{$\mathrm{HB}$} & \multirow[b]{2}{*}{$\mathrm{HFC}$} & \multicolumn{2}{|c|}{ State variable } & \multirow[b]{2}{*}{ POC } & \multirow[b]{2}{*}{ DOC } & \multirow[b]{2}{*}{ N1 } & \multirow[b]{2}{*}{ N2 } & \multirow[b]{2}{*}{$\mathrm{P}$} \\
\hline & & & & & & Z1 & Z2 & & & & & \\
\hline \multicolumn{13}{|l|}{ Forcing variable } \\
\hline Incident radiation & $0.62 / 16$ & - & - & - & - & $0.012 / 23$ & - & - & - & - & $0.58 / 11$ & l $0.03 / 13$ \\
\hline Temperature & $0.42 / 11$ & $2.86 / 24$ & - & $0.025 / 22$ & $0.003 / 18$ & $\mathbf{8 0 . 0 1 9 / 3 9}$ & 9 0.004/62 & $2-$ & $0.3 / 16$ & $0.31 / \mathbf{1 8}$ & $0.85 / 16$ & $0.05 / 21$ \\
\hline $\begin{array}{l}\text { Radiation + } \\
\text { temperature }\end{array}$ & $1.05 / 27$ & $2.97 / 25$ & - & $0.030 / 26$ & $0.003 / 1$ & $\mathbf{9 0 . 0 2 0 / 4 1}$ & $10.004 / 62$ & $2-$ & $0.33 / 18$ & $0.36 / 20$ & $1.40 / 26$ & $0.068 / 28$ \\
\hline $\begin{array}{l}\text { Light attenuation } \\
\text { coefficient }\end{array}$ & $0.42 / 11$ & $2.84 / 24$ & - & - & - & 0.005/11 & - & - & - & $0.20 / 11$ & $0.91 / 17$ & $0.049 / 20$ \\
\hline $\begin{array}{l}\text { Top-bottom salinity } \\
\text { difference }\end{array}$ & - & $2.56 / 22$ & $2.47 / 35$ & - & - & - & $0.0007 / 11$ & $10.045 / 15$ & $5-$ & $0.35 / 20$ & $1.12 / 21$ & $0.056 / 23$ \\
\hline \multicolumn{13}{|l|}{ Boundary condition } \\
\hline PP from up-river & $1.64 / 42$ & - & - & - & - & $0.005 / 10$ & -0. & $.037 / 12$ & - & - & - & - \\
\hline NP from up-river & - & $8.32 / 70$ & - & $0.012 / \mathbf{1 1}$ & $0.002 / 1$ & $40.020 / 42$ & -0. & $.034 / 11$ & $0.30 / 16$ & $0.24 / 14$ & $1.21 / 22$ & $0.042 / 17$ \\
\hline MP from up-river & - & - & $9.6 / \mathbf{1 3 6}$ & - & - & - & - & - & - & - & - & 0.026/11 \\
\hline N2 from up-river & - & - & - & - & - & - & - & - & - & - & $3.3 / 60$ & - \\
\hline PP from bottom water & er - & - & - & - & - & - & - & - & - & - & - & - \\
\hline NP from bottom water & er - & - & - & - & - & $0.010 / 20$ & - & - & - & - & - & $0.039 / 16$ \\
\hline MP from bottom water & er - & - & $1.71 / 24$ & - & - & - & - & - & - & - & - & - \\
\hline N1 from bottom water & er - & - & - & - & - & - & - & - & - & $0.37 / 21$ & $0.61 / 11$ & - \\
\hline $\mathrm{P}$ from bottom water & er - & - & - & - & - & - & - & - & - & - & - & $0.069 / 29$ \\
\hline
\end{tabular}

that, unlike small cells (pico-, nanophytoplankton), the dynamics of large cells (microphytoplankton) may be affected by hydrodynamic processes such as sinking and vertical diffusion that are determined by cell size and bed-shear velocity respectively.

Ammonium (N1) was sensitive to changes in the C:N ratio for heterotrophs. Nitrite + nitrate (N2) was not sensitive to denitrification rate or to bed-shear velocity. Orthophosphate concentration (P) was sensitive to changes in the C:P ratio, but was not sensitive to bedshear velocity. Sensitivity of the nutrient state variables to changes in the $\mathrm{C}: \mathrm{N}$ or $\mathrm{C}: \mathrm{P}$ ratios indicate the importance of using appropriate (confirmed) values for the ratios in the model.

Mesozooplankton were not sensitive to bed-shear velocity $(u$. ), but were highly sensitive to changes in most parameters tested, exhibiting high percentage changes $(\geq 20 \%)$ in biological loss terms such as mortality $\left(r_{\mathrm{m}}\right)$, sloppy feeding $\left(f_{\mathrm{sf}}\right)$, egestion $\left(f_{\text {eg }}\right)$, and loss to higher consumers (Z2M) as well as cell size ( 20\%) (Sin \& Wetzel 2002). These results suggest that mesozooplankton dynamics are more likely to be affected by biological processes than by hydrodynamic variables.

\section{Model sensitivity: forcing variables and physical properties}

The average RMS and percentage change in the concentrations of the state variables are presented in
Table 2 given $\pm 10 \mathrm{E} \mathrm{m}^{-2} \mathrm{~d}^{-1}$ change in incident solar radiation, $\pm 2{ }^{\circ} \mathrm{C}$ temperature change, $\pm 20 \%$ changes in the light attenuation coefficient and top-to-bottom salinity difference. The combined effects of changes in solar radiation and temperature are also presented given the co-variance between the 2 variables. Picophytoplankton (PP), microzooplankton (Z1), nitrite + nitrate (N2) and orthophosphate (P) concentrations were sensitive to changes in incident daily solar radiation. All state variables except microphytoplankton and POC were sensitive to changes in temperature and light + temperature, suggesting that compared with solar radiation, temperature is more probably the dominant controlling factor. Small (pico- and nano-) phytoplankton, microzooplankton and nutrient pools were sensitive to changes in $k_{\mathrm{d}}$ (light attenuation coefficient). Nano- and microphytoplankton, mesozooplankton, POC and nutrient pools were sensitive to changes in top-to-bottom salinity difference (Table 2), indicating that the water-column stratification and destratification cycle plays an important role in the dynamics of larger plankton and nutrients.

The different model responses of pico-, nano- and microphytoplankton to change in the forcing variables suggest that solar radiation, temperature and vertical salinity distribution may differentiate the production and biomass accumulation of each phytoplankton size class. Fig. 2 shows the different responses of pico-, nano- and microphytoplankton to changes in incident solar radiation and temperature. An increase (or decrease) in solar 
radiation and temperature increased (or decreased) pico- and nano-chlorophyll $a$ $(\mathrm{chl}$ a) concentrations, whereas an increase in light level and temperature did not affect micro-chl a concentrations. The effects of change in the top-to-bottom salinity difference on phytoplankton and nutrients are shown in Fig. 3. A change in salinity difference did not affect picophytoplankton chlorophyll concentrations (Fig. 3A), but did affect both nanoand microphytoplankton concentrations (Fig. 3B,C). A $20 \%$ increase in the salinity difference increased nano-chl a concentrations and decreased micro-chl a concentrations, suggesting a different response of each cell size class to the York River stratification-destratification cycle. The result indicates that nanophytoplankton chl a biomass increases as the water column becomes stratified, while microphytoplankton chl a biomass decreases.

Ammonium and orthophosphate responded negatively to changes in salinity difference, especially during summer (Fig. 3D,F) while nitrite + nitrate responded positively to the change, especially during winter-spring (Fig. 3E). This result indicates that concentrations of ammonium and orthophosphate increased as the water column destratified, but nitrite + nitrate concentrations increased as the water column became stratified.

\section{Model sensitivity: boundary conditions}

The average RMS and percentage change in the state variables are also presented in Table 2, given \pm 10 and $\pm 20 \%$ changes in incoming source water from upriver and from bottom water respectively. Only picophytoplankton, microzooplankton and POC were sensitive to changes in picophytoplankton densities in the incoming source water from upriver. All state variables except picophytoplankton, microphytoplankton and mesozooplankton were sensitive to change in nanophytoplankton chl a concentrations in incoming source water from upriver. Microphytoplank-
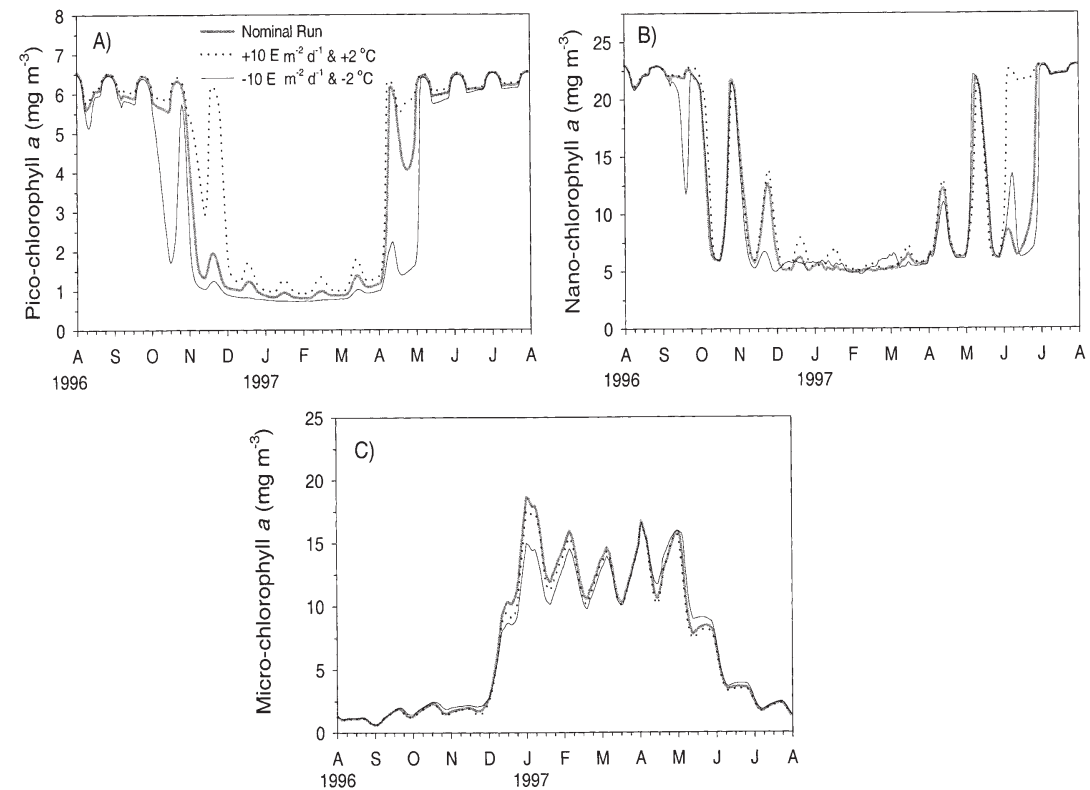

Fig. 2. Sensitivity results for pico-, nano-, and micro-chl a $\left(\mathrm{mg} \mathrm{m}^{-3}\right)$. Effects of change in light and temperature were examined, given $\pm 10 \mathrm{E} \mathrm{m}^{-2} \mathrm{~d}^{-1}$ change in incident solar radiation and $\pm 2{ }^{\circ} \mathrm{C}$ change in temperature
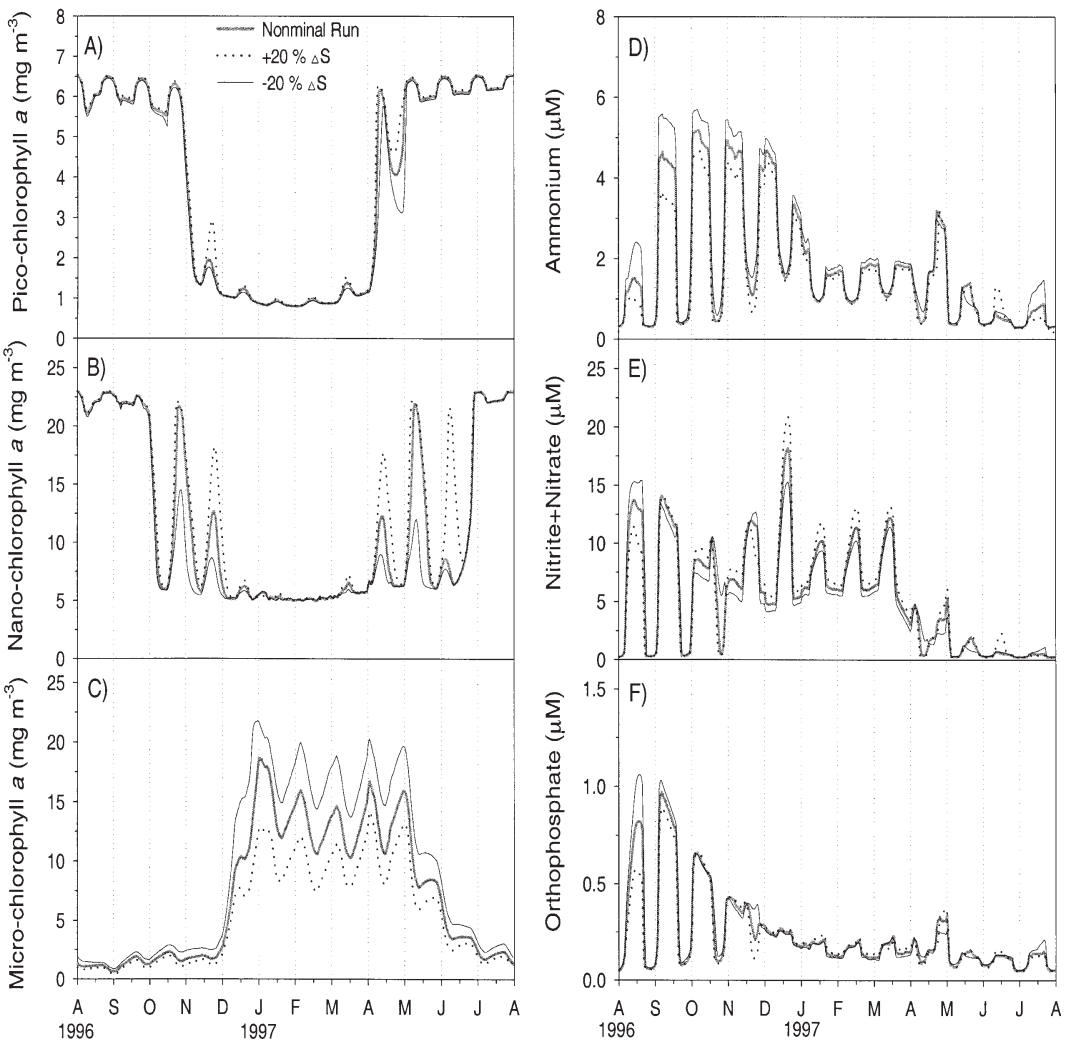

Fig. 3. Sensitivity results for pico-, nano-, micro-chl $a$, ammonium, nitrite + nitrate and orthophosphate. Effects of change in top-to-bottom salinity difference were examined by comparing chl a biomass and nutrient concentrations between a nominal run and sensitivity runs, given $\pm 20 \%$ change in top-tobottom salinity difference 

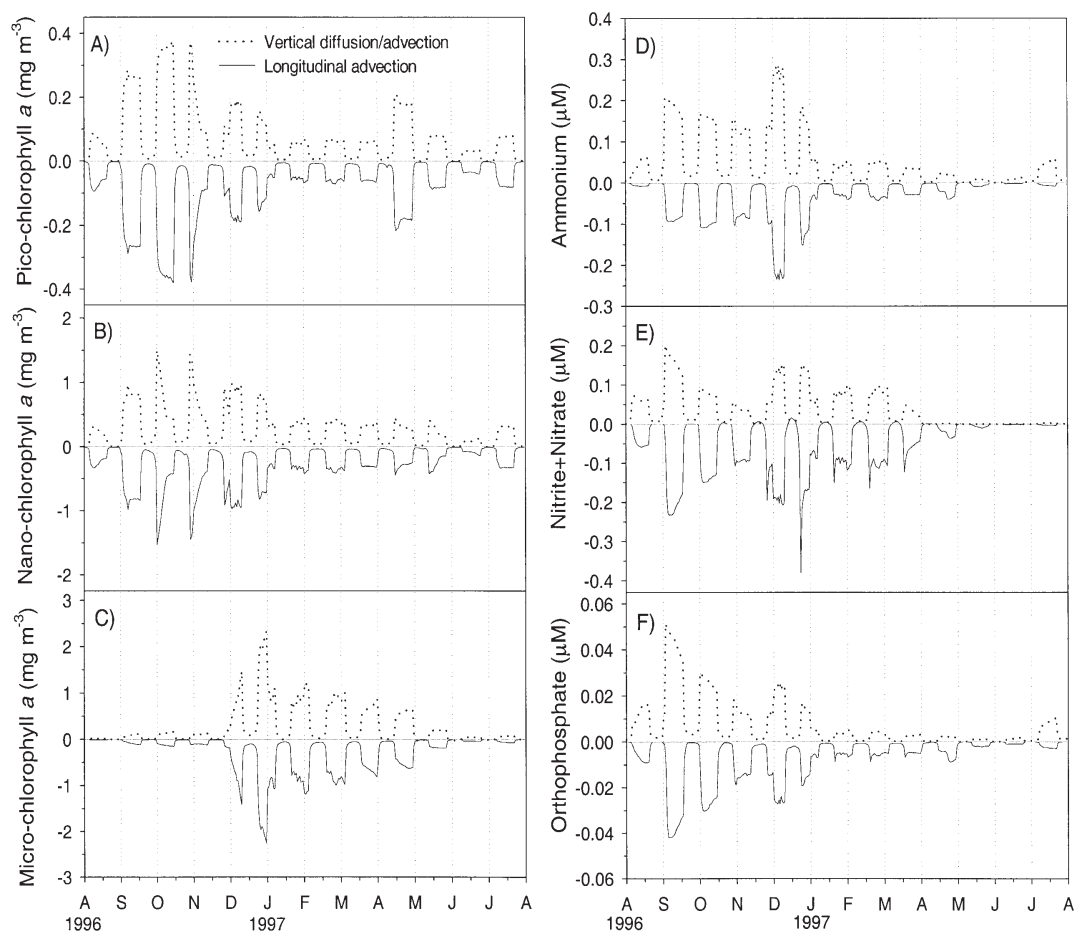

Fig. 4. Time series of daily changes in concentrations of pico-, nano-, and micro-chl $a$ and nutrient (ammonium, nitrite + nitrate, orthophosphate) arising from vertical advection/diffusion and longitudinal advection
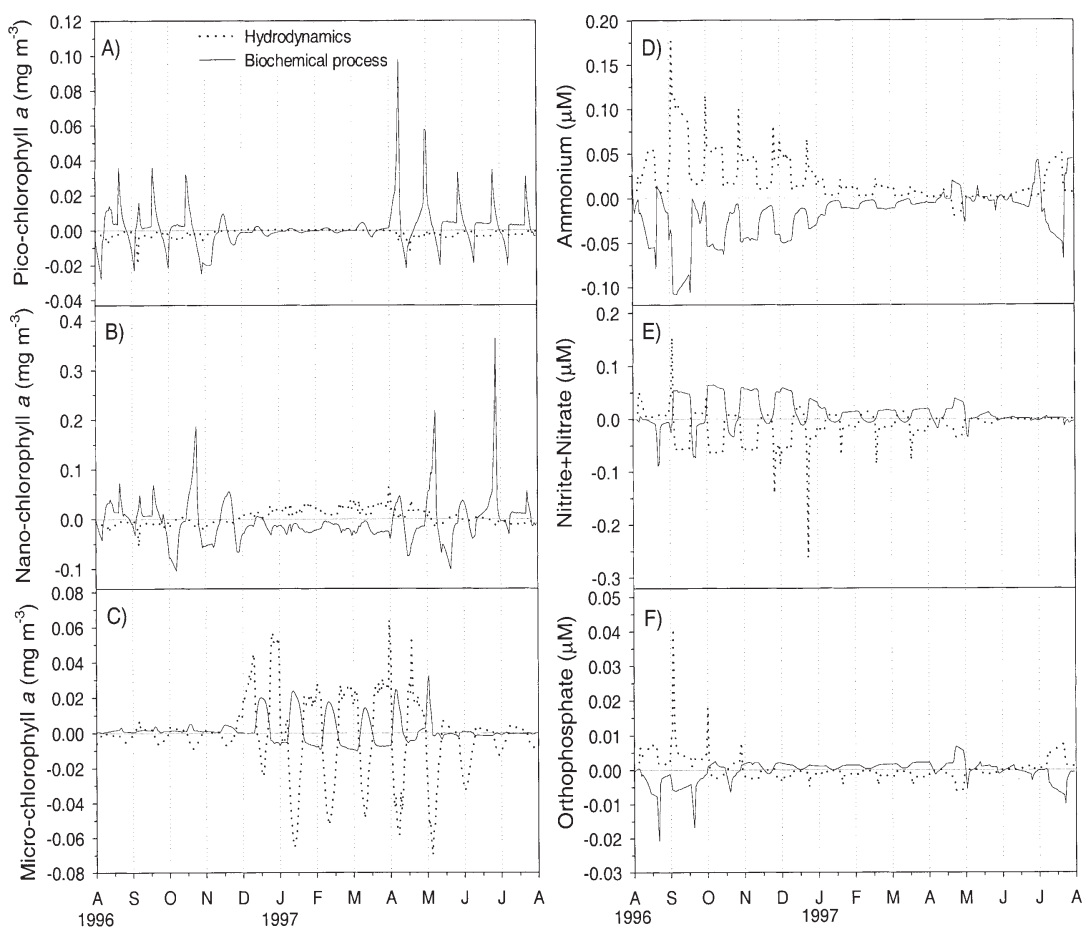

Fig. 5. Time series of daily changes in concentrations of pico-, nano-, and microchl $a$ and nutrient (ammonium, nitrite + nitrate, orthophosphate) arising from hydrodynamic mechanisms (advection + vertical diffusion) and biochemical processes ton and orthophosphate were sensitive to change in microphytoplankton chl a concentrations in incoming source water from upriver. The percentage change in microphytoplankton was highest $(136 \%)$ compared with pico$(42 \%)$ and nanophytoplankton $(70 \%)$, suggesting that microphytoplankton is most affected by input of cells from upriver, probably through longitudinal transport (advection). Surprisingly, no phytoplankton state variable was sensitive to change in nitrite + nitrate concentrations of the incoming source water. Only nitrite + nitrate was sensitive to change in the incoming source, suggesting that nitrite + nitrate from upriver may not be a major factor controlling phytoplankton production in the lower, mesohaline area of the estuary. No state variables were sensitive to the incoming source for picophytoplankton from bottom water, whereas microzooplankton and orthophosphate were sensitive to changes in the incoming source of nanophytoplankton from bottom water. Unlike pico- and nanophytoplankton, microphytoplankton were sensitive to changes in the incoming source from bottom water, as were ammonium and orthophosphate. These results suggest that vertical diffusion and advection may be a major mechanism affecting the dynamics of large phytoplankton and nutrients in surface water, especially ammonium and orthophosphate, by transporting large phytoplankton and nutrients regenerated from the bottom water.

\section{Model sensitivity: hydrodynamic processes}

Since the removal of 1 or 2 hydrodynamic processes are not physically realizable scenarios, it is necessary to examine the time series of each term for vertical flux (advection and diffusion) including sinking, longitudinal import/export (advection) and in situ production in order to determine their relative importance. Fig. 4 shows the changes in concentrations of phytoplankton and nutrients arising from 
vertical advection and diffusion versus longitudinal advection. It is evident that vertical flux serves as a 'source' of phytoplankton and nutrients, whereas longitudinal transport serves as a 'sink' in the model, suggesting that these 2 terms are offset in the model simulation. The scale or magnitude of the source and sink terms also varies with season, cell size and nutrient species. The seasonality of microphytoplankton is prominent (Fig. 4C), being high during the cold season but low during the warm season. Vertical flux is more important than longitudinal advection for ammonium and orthophosphate pools during the warm season, whereas longitudinal advection is more important for nitrite + nitrate pools during the cold season (Fig. 4D,E,F).

The direct effects of the combined hydrodynamic processes were compared with in situ production of phytoplankton and nutrients to determine the role of hydrodynamics and biological-chemical processes in the watercolumn dynamics of the York River system (Fig. 5). Since vertical advection/ diffusion serves as a source mechanism and longitudinal advection is a sink mechanism in most cases (see Fig. 4), positive values represent vertical flux alone and negative values denote longitudinal export. Changes in pico- and nanophytoplankton biomass due to hydrodynamic processes are small and vary little over time, whereas in situ production of small cells is large and fluctuates greatly, except during the winterspring period (Fig. 5A,B). However, changes in microphytoplankton biomass due to hydrodynamics are relatively large, and fluctuate greatly between 'source' and 'sink' at the scale of neap-spring tidal cycles during the winter-spring (Fig. 5C). In situ production also fluctuates during winter-spring, but its impact is small compared to that of hydrodynamic processes, although the effects of the two are inversely related. The results suggest that in situ production is more important than hydrodynamic controls for small cells, whereas hydrodynamic processes are more important for large cells.

Hydrodynamics also play a role as a 'source' mechanism for ammonium throughout the year, especially during summer and fall, whereas biochemical processes generally serve as a 'sink' mechanism, especially during the winter season (Fig. 5D). The pattern is reversed for nitrite + nitrate: here hydrodynamics serve as a 'sink' and bio-chemical processes serve as a 'source' mechanism (Fig. 5E). For orthophosphate, hydrodynamics play a role as a 'source' and biochemical processes serve as a 'sink' mechanism during summer and fall, but the roles are reversed during winter and spring (Fig. 5F).

To further investigate the potential influences of physical processes, Fig. 6 shows the model outputs for phytoplankton chl a biomass and nutrients when the processes of advection and diffusion were removed from the model. The chl a concentrations of picophytoplankton did not change greatly but nanophytoplankton chl a concentrations increased slightly. The winterspring blooms of microphytoplankton completely disappeared when diffusion and advection were removed, suggesting that these processes influence the accumulation of large cells during winter-spring in the mesohaline area of the York River estuary. Oscillations in nutrient concentrations observed in the nominal model run during the warm season in 1996 disappeared. The 1996 summer peaks in the nutrients also disappeared indicating the importance of physical processes in nutrient dynamics in the study area. Percentage changes in concentrations of microphytoplankton, mesozooplankton, and all nutrient pools were greater than $50 \%$ when diffusion and vertical advection were removed from the model (data not shown).

In order to investigate the role of diffusion and vertical advection as a factor influencing phytoplankton and nutrient dynamics, we examined the relationship 

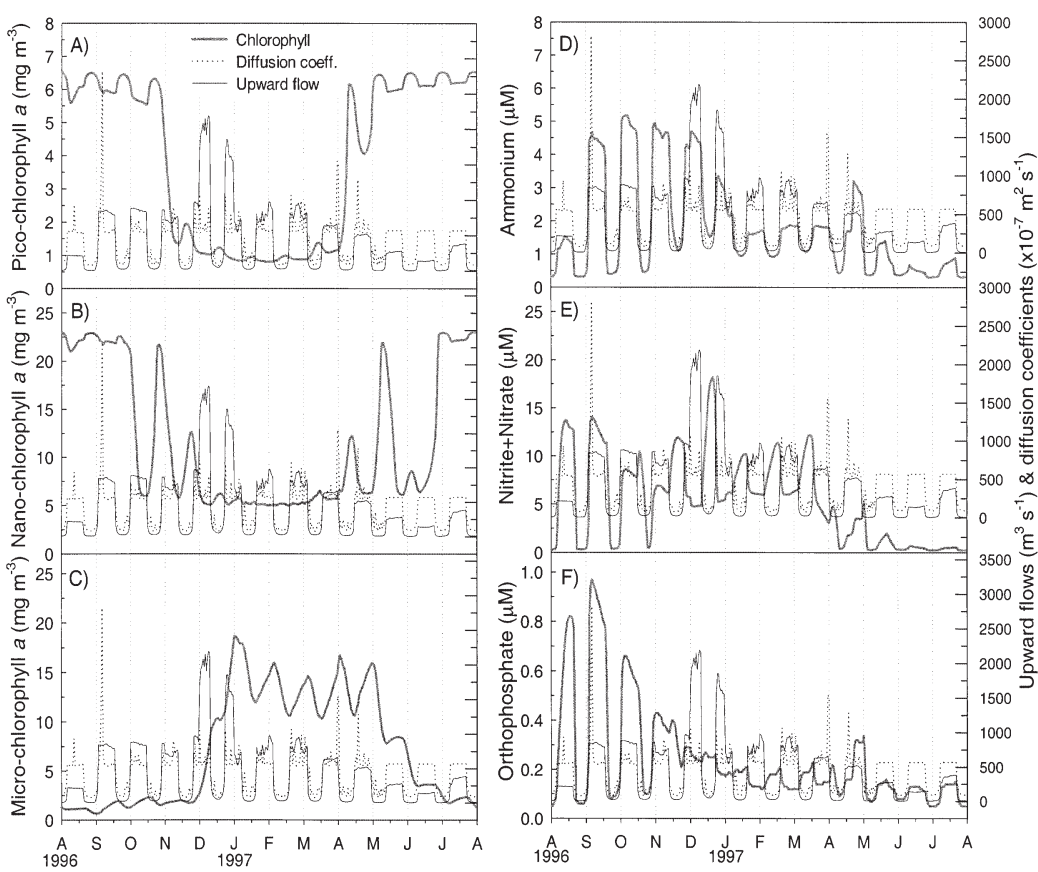

Fig. 7. Distributions of diffusion coefficient, chl a (pico-, nano-, and micro) and nutrients from the nominal model run of the ecosystem model

pendent metabolism, since phytoplankton size classes were sensitive to changes in incident solar radiation and temperature. Unlike large cells (microphytoplankton), the seasonal distributions of small cells (see Fig. 2) were also in phase with those of incident solar radiation and temperature (high during summer, low during winter), providing additional support for the hypothesis. Results from field observations over an annual cycle (Sin et al. 2000) showed a significant and positive correlation between pico-sized chl $a$ and temperature, indicating the importance of temperature-dependent metabolism coupled with light availability.

Nano- and microphytoplankton were especially sensitive to changes in topto-bottom salinity differences, suggesting that the phytoplankton may be regulated strongly by physical processes such as tidal mixing. However, the response of the phytoplankton community to changes in top-to-bottom salinity differences was dependent on

between upward flows as well as diffusion coefficients (vertical eddy diffusivity, $D$ ) and the model predictions for the chl a biomass of phytoplankton and nutrient pools (Fig. 7). The chl a biomass of small (pico-, nano-) cells was related negatively to the coefficients and upward flows at the scale of neap-spring tidal cycles (Fig. 7A,B). On the other hand, the chl a biomass of large cells was related positively (slightly) to the coefficients and upward flows (Fig. 7C), suggesting that the influence of hydrodynamic processes on phytoplankton dynamics is dependent on size structure and operates at the neap-spring fortnightly time scale. Ammonium showed a positive relationship with vertical eddy diffusivity and upward flow throughout the annual cycle (Fig. 7D). Nitrite + nitrate and orthophosphate showed a positive relationship with eddy diffusivity during the warm season, but were related negatively during the cold season (Fig. 7E,F). These results suggest that vertical diffusion (tidal mixing) and advection may play an important role in size-structured phytoplankton and nutrient dynamics in the surface water of the lower York River estuary.

\section{DISCUSSION}

Model sensitivity analyses of forcing variables (Table 2) suggest that small (pico-, nano-) phytoplankton cells may be regulated by light- and temperature-de- cell size (Fig. 3). The chl a biomass of small cells, especially nanophytoplankton, increased during the warm season (especially in spring and fall) when the salinity difference increased $(+20 \%)$, whereas the biomass of large cells (microphytoplankton) decreased (Fig. 3A,B,C). This result suggests that the biomass accumulation of small cells may be enhanced by stratification whereas that of large cells may be enhanced by destratification. This conclusion was reinforced when we examined the relationship between phytoplankton and diffusion coefficient distributions. The relationships were negative for small cells and positive for large cells over a fortnightly cycle (Fig. 7). The pattern for small cells agrees with observations by Ray et al. (1989) in the mesohaline zone of the York River estuary. Peak abundances of cyanobacteria and diatoms observed during periods of stratification and minima during periods of destratification (Ray et al 1989). Using a numerical algal growth model controlled only by light limitation, Ray et al. (1989) concluded that cyanobacterial growth is limited by light availability in the surface water, since vertical mixing increases the mixed layer depth and decreases light. A food-web model (Eldridge \& Sieracki 1993) documented that changes in mixed-layer depth determines light availability regulating cyanobacterial growth rates in the mesohaline zone of the York River estuary. Therefore, light availability coupled with the watercolumn stratification-destratification cycle may be the 
major controlling factor of the growth of small cells during the warm season in surface waters of the mesohaline zone. Based on long-term data analysis and a simulation model for the South San Francisco Bay, Cloern (1991) also documented that the temporal variation of phytoplankton biomass and production is largely driven by variations in physical forcing that control vertical tidal mixing. The model simulated the bloom dominated by nanophytoplankton which occurred under slow vertical mixing conditions as a result of rapid phytoplankton growth in the euphotic zone, coupled with slow sinking and vertical diffusion from the surface water to the lower water column and sediment where grazing occurs. The models (Ray et al. 1989, Cloern 1991, Eldridge \& Sieracki 1993), however, did not include nutrients, which also serve as an important controlling factor for phytoplankton dynamics. The results of the present study suggest that tidal mixing may be a major mechanism for supplying benthicregenerated nutrients, especially ammonium and orthophosphate, to the surface water during the warm season, and that the nutrients released from the bottom water may be an important source for growth of small cells under elevated light levels during stratification. During late summer and early fall, high temperatures increase the remineralization of organic nitrogen and phosphate in sediments, thereby releasing ammonium and orthophosphate which accumulate in bottom water under stratified conditions and are supplied to the surface water through spring-tide destratification (tidal mixing) in the lower York River (Webb \& D'Elia 1980). The importance of the water column stratification-destratification cycle for nutrient supply was also indicated by positive correlations between bottom water ammonium and orthophosphate versus surfacebottom salinity difference (Sin et al. 1999). Tremblay et al. (1997) also observed that small-sized phytoplankton $(>5 \mu \mathrm{m})$ were dominant when nitrate concentrations were low and the water column was stratified during summer in the Lower St. Lawrence Estuary.

Microphytoplankton were sensitive to changes in bedshear velocity as well as changes in the top-bottom salinity difference (Table 1). The chl a biomass of large cells was positively related to diffusion coefficients and vertical flows on a short-term basis during winter-spring (Fig. 7C). These results suggest that the biomass of large cells may be controlled by the physical processes of vertical diffusion and advection. The effects of diffusion and advection on phytoplankton dynamics were investigated by examining changes in the chl a biomass of phytoplankton attributable to hydrodynamics (Figs. 4 \& 5) by removing the physical terms from the nominal model (Fig. 6). Microphytoplankton were highly sensitive to hydrodynamics (Figs. 5C \& 6C), suggesting that these populations may be controlled by physical processes including advection and diffusion in the lower part of the York River system. These model analyses also suggested that winter-spring blooms of large cells are most probably the consequence of vertical mixing and transports rather than in situ production, considering their response to the physical processes (Figs. 5C \& 6C) and nutrient input from upriver and bottom water (Table 2). Based on the field observations and long-term data analyses alone, it was difficult to clarify the relative importance of in situ production supported by riverine $\mathrm{N}$ input versus advective transport from the upper river and/or bottom water as a major source of winter-spring blooms of microphytoplankton (Sin et al. 2000). Seasonal distributions of chl a from long-term EPA monitoring data showed that maximum chl a blooms which may be controlled by riverine $\mathrm{N}$ inputs develop in a region further upriver than the region of the estuary modeled here (Sin et al. 1999). The importance of hydrodynamic processes to the large-sized phytoplankton was also documented by Tremblay et al. (1997). The production of large-sized phytoplankton was mainly controlled by the vertical mixing of the water column associated with longitudinal advection, which affects nutrient supply and the residence time of diatoms in the euphotic zone in the lower St. Lawrence Estuary.

Results from long-term EPA data analyses also showed that bottom concentrations of chlorophyll were much higher than surface concentrations during winter-spring at the mouth (Stn WE4.2) of the York River (Fig. 8). The major contribution to the higher chlorophyll in the bottom water was made by microphytoplankton-sized cells, based on field observations at a station in the mesohaline zone of the York River estu-

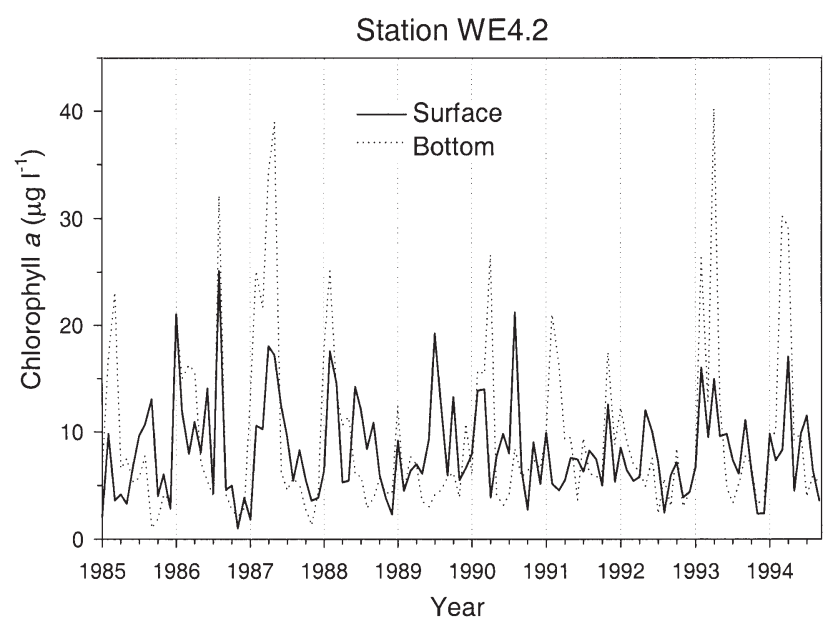

Fig. 8. Temporal distributions of chl a in the surface and bottom water at Stn WE4.2 (near mouth of the York River estuary) from 1985 to 1994. Stn WE4.2 is one of the stations which have been monitored by EPA Chesapeake Bay Monitoring Program in the York River 
ary (Sin et al. 2000). These observations suggest that high bottom-water chl a concentrations of large cells is most probably the major source for winter-spring blooms of large cells by vertical transport, including advection and diffusion, in the lower York River estuary. In the model sensitivity analyses of incoming sources of microphytoplankton from bottom water (Table 2), microphytoplankton alone were sensitive to changes in the incoming source, while other size classes were not. The role of advective transport in the development of winter-spring blooms was also documented by Malone et al. (1980) in the lower Hudson River estuary, which is a partially mixed estuary as is the York River estuary. Malone et al. (1980) found that chl a concentrations of net phytoplankton $(>20 \mu \mathrm{m})$ in the lower estuary were controlled by advective transport of bottom chl a from adjacent coastal waters during winter and early spring when phytoplankton growth and grazing by macrozooplankton appeared low. Although it is difficult to identify the principal mechanisms resulting in the high chlorophyll in the bottom water of the lower York River estuary, it is hypothesized that the major processes may be sinking of large-sized cells advected from upriver in surface water and/or net upstream transport of large cells in bottom water from Chesapeake Bay.

Based on the results from these modeling analyses coupled with field observations, size-structured phytoplankton dynamics are more likely to be controlled by physical processes such as light, temperature and hydrodynamics than by biological or chemical processes in the lower mesohaline York River estuary. The long-term EPA data analyses (Sin et al. 1999) suggested that phytoplankton dynamics in the York River estuary may be controlled by abiotic mechanisms (i.e. bottom-up control) rather than trophic, biotic interactions (i.e. top-down control). The results of the model sensitivity analyses (Table 1) support this conclusion, since phytoplankton were not sensitive to changes in parameters related to trophic interactions or other biological processes including feeding preference $\left(P_{i j}\right)$, mortality rate $\left(r_{\mathrm{m}}\right)$ and exudation rate $\left(r_{\mathrm{ex}}\right)$. Microphytoplankton were sensitive to change in cell size (mass, $M)$ and bed-shear velocity $(u$.) related to hydrodynamic processes such as sinking and vertical mixing. However, mesozooplankton were sensitive to changes in parameters related to biological processes, suggesting that they may be controlled by biotic factors (e.g. grazing) rather than abiotic mechanisms.

\section{CONCLUSIONS}

We used a tidally-averaged, size-structured ecosystem model that incorporated physical mechanisms in- cluding advection and diffusion with a neap-spring, fortnightly tidal cycle to investigate factors potential controlling size-structured phytoplankton and nutrient dynamics in the mesohaline zone of the York River estuary. The realistic ecosystem model and analyses with the model showed that growth of small cells (pico-, nano-) may be regulated by light availability and temperature dependent metabolism on a seasonal basis. The simulated high-frequency (daily) fluctuations of small-cell population densities were phased with the neap-spring (fortnighty) tidal cycle indicating that growth of cells over shorter time frames may be controlled by light availability coupled with water column stratification-destratification, and supported by the input of benthic-regenerated nutrients into the surface water through vertical mixing, especially during the warm season in the mesohaline zone. Their growth may be limited by light availability during destratification (tidal mixing), since vertical mixing increases the mixed layer depth and decreases light. In contrast to small cells, the biomass accumulation of large cells may be a consequence of vertical and longitudinal transport of cells through advection and diffusion from upriver and bottom water rather than in situ production in the region of model application. The model analyses supported the hypothesis established from analyses of long-term EPA datasets that phytoplankton dynamics appear to be controlled to a large extent by resource limitation (bottom-up control) rather than by biotic interactions such as zooplankton grazing (top-down control). Larger mesozooplankton appear to be controlled by biotic mechanisms. This study suggests that it is important to refine the physical description in the ecosystem simulation model and to consider quality (size structure) as well as quantity (biomass) of phytoplankton to better understand phytoplankton and nutrient dynamics in coastal estuarine environments.

Acknowledgements. We thank Dr H. W. Ducklow, Dr A. Y. Kuo and anonymous reviewers for their constructive discussions and insight which greatly improved the manuscript. This research was supported in part by grants to Dr T. Dai and R. L. W. from the Virginia coastal resources management program, the US EPA Chesapeake Bay Program (CB993267-02-1) and AMOCO, Inc., Yorktown, Virginia. This is contribution number 2446 from the Virginia Institute of Marine Science, School of Marine Science of the College of William and Mary, Virginia.

\section{LITERATURE CITED}

Aksnes DL, Lie U (1990) A coupled physical-biological pelagic model of a Shallow Sill Fjord. Estuar Coast Shelf Sci 31: 459-486

Alpine AE, Cloern JE (1992) Trophic interactions and direct physical effects control phytoplankton biomass and production in an estuary. Limnol Oceanogr 37:946-955

Armstrong RA (1994) Grazing limitation and nutrient limita- 
tion in marine ecosystems: steady state solutions of an ecosystem model with multiple food chains. Limnol Oceanogr 39:597-608

Boyer JP, Christian RR, Stanley DW (1993) Patterns of phytoplankton primary productivity in the Neuse River estuary, North Carolina, USA. Mar Ecol Prog Ser 97:287-297

Caraco NF, Cole JJ, Raymond PA, Strayer DL, Pace ML, Findlay SEG, Fisher DT (1997) Zebra mussel invasion in a large, turbid river: phytoplankton response to increased grazing. Ecology 78:588-602

Carpenter SR, Kitchell JF, Hodgson JR (1985) Cascading trophic interactions and lake productivity. BioScience 35: 634-639

Carpenter SR, Kitchell JF, Hodgson JR, Cochran PA, Elser JJ, Elser MM, Lodge DM, Kretchmer D, He X, von Ende CN (1987) Regulation of lake primary productivity by food web structure. Ecology 68:1863-1876

Cloern JE (1991) Tidal stirring and phytoplankton bloom dynamics in an estuary. J Mar Res 49:203-221

Cloern JE (1996) Phytoplankton bloom dynamics in coastal ecosystems: a review with some general lessons from sustained investigation of San Francisco Bay, California. Rev Geophys 34:127-168

Cloern JE, Alpine AE, Cole BE, Wong RLJ, Arthur JF, Ball MD (1983) River-discharge controls phytoplankton dynamics in the Northern San Francisco Bay Estuary. Estuar Coast Shelf Sci 16:415-429

Eldridge PM, Sieracki ME (1993) Biological and hydrodynamic regulation of the microbial food web in a periodically mixed estuary. Limnol Oceanogr 38:1666-16679

Gallegos CL, Jordan TE, Correll DL (1992) Event-scale response of phytoplankton to watershed inputs in a subestuary: timing, magnitude, and location of blooms. Limnol Oceanogr 37:813-828

Haas LW (1975) Plankton dynamics in a temperate estuary with observations on a variable hydrographic condition. Doctoral dissertation. School of Marine Science, College of William and Mary, Gloucester Point, VA

Hyer PV (1977) Water quality model of York River, Virginia. Special Scientific Report No. 146. Virginia Institute of Marine Science, School of Marine Science, College of William and Mary, Gloucester Point, VA

Kivi K, Kaitala S, Kuosa H, Kuparinen J, Leskinen E, Lignell R, Marcussen B, Tamminen T (1993) Nutrient limitation and grazing control of the Baltic plankton community during annual succession. Limnol Oceanogr 38:893-905

Editorial responsibility: Otto Kinne (Editor), Oldendorf/Luhe, Germany
Madariaga Ide, Gonzalez-Azpiri L, Villate F, Orive E (1992) Plankton responses to hydrological changes induced by freshets in a shallow mesotidal estuary. Estuar Coast Shelf Sci 35:425-434

Malone TC, Chervin MB (1979) The production and fate of phytoplankton size fractions in the plume of Hudson River, New York Bight. Limnol Oceanogr 24:683-696

Malone TC, Neale PJ, Boardman D (1980) Influences of estuarine circulation on the distribution and biomass of phytoplankton size fractions. In: Kennedy V (ed) Estuarine perspectives. Academic Press, New York, p 249-262

Malone TC, Crocker LH, Pike SE, Wendler BW (1988) Influences of river flow on the dynamics of phytoplankton production in a partially stratified estuary. Mar Ecol Prog Ser 48:235-249

Pennock JR (1985) Chlorophyll distributions in the Delaware Estuary: regulation by light-limitations. Estuar Coast Shelf Sci 21:711-725

Pennock JR, Sharp JH (1994) Temporal alternation between light- and nutrient-limitation of phytoplankton in a coastal plain estuary. Mar Ecol Prog Ser 111:275-288

Ray TR, Haas LW, Sieracki ME (1989) Autotrophic picoplankton dynamics in a Chesapeake Bay sub-estuary. Mar Ecol Prog Ser 52:273-285

Sin Y, Wetzel RL (2002) Ecosystem modeling analysis of sizestructured phytoplankton dynamics in the York River estuary, Virginia (USA). I. Development of a plankton ecosystem model with explicit feedback-controls and hydrodynamics. Mar Ecol Prog Ser 228:75-90

Sin Y, Wetzel RL, Anderson IC (1999) Spatial and temporal characteristics of nutrient and phytoplankton dynamics in the York River estuary, Virginia: analyses of long term data. Estuaries 22:260-275

Sin Y, Wetzel RL, Anderson IC (2000) Seasonal variations of size fractionated phytoplankton along the salinity gradient in the York River estuary, Virginia (USA). J Plankton Res 22:1945-1960

Tremblay JE, Legendre L, Therriault JC (1997) Size-differential effects of vertical stability on the biomass and production of phytoplankton in a large estuarine system. Estuar Coast Shelf Sci 45:415-431

Tilman D (1982) Resource competition and community structure. Princeton University Press, Princeton, NJ

Webb KL, D'Elia CF (1980) Nutrient and oxygen redistribution during a spring neap tidal cycle in a temperate estuary. Science 207:983-985

Submitted: August 8, 2000; Accepted: April 24, 2001

Proofs received from author(s): February 12, 2002 